\title{
Land Use and Land Cover Changes in Awash National Park, Ethiopia: Impact of Decentralization on the Use and Management of Resources
}

\author{
Solomon Belay¹, Aklilu Amsalu², Eyualem Abebe ${ }^{3 *}$ \\ ${ }^{1}$ Department of Geography, Jigjiga University, Jijiga, Ethiopia \\ ${ }^{2}$ Department of Geography, Addis Ababa University, Addis Ababa, Ethiopia \\ ${ }^{3}$ Department of Natural Science, Elizabeth City State University, Elizabeth City, USA \\ Email: ${ }^{*}$ Ebabebe@ecsu.edu
}

Received 26 September 2014; revised 25 October 2014; accepted 30 October 2014

Copyright (C) 2014 by authors and Scientific Research Publishing Inc.

This work is licensed under the Creative Commons Attribution International License (CC BY). http://creativecommons.org/licenses/by/4.0/

\section{(c) (i) Open Access}

\begin{abstract}
We analyzed the magnitude of land use land cover changes and identified drivers of those changes at Awash National Park, Ethiopia, using aerial photographs, satellite images and field observation. Scattered bushland-the most important habitat for the wild animals, declined drastically. Areas under grassland, farmland or open land increased over the study period. Policy and park border demarcation issues were identified as drivers of change before 1995 (before decentralization), whereas livestock grazing was indicated to be the leading driver of change after 1995. Major events and causes that largely explained these changes include immigration of the Ittu community, land tenure system, drought, poaching, use policy issues and regional economic and infrastructural development. Our study reveals that the sustainability of the park calls for an immediate action to reduce the ever increasing human and livestock pressure on park resources.
\end{abstract}

\section{Keywords}

Land Use, Land Cover, Decentralization, Geographic Information System (GIS), Awash National Park, Ethiopia

\section{Introduction}

The central theme in land use land cover change (LULC) issues is the interaction between humans and the envi"Corresponding author.

How to cite this paper: Belay, S., Amsalu, A. and Abebe, E. (2014) Land Use and Land Cover Changes in Awash National Park, Ethiopia: Impact of Decentralization on the Use and Management of Resources. Open Journal of Ecology, 4, 950-960. 
ronment they live in [1]. The magnitude of such an interaction is broad [2] and includes the interface between resources, stakeholders and institutions at multiple levels [3]. Moreover, LULC has a direct relationship with productivity of the land and biological diversity in protected areas [4]. As a result, monitoring its dynamics and impact, and identifying root causes of its change are critical to environmental sustainability efforts [5] [6]. Reference [7] summarized the fundamental causes of land use changes under two major categories i.e. endogenous causes and exogenic causes. At the country level, root causes of LULC change could be demographic, institutional, political, socio-cultural, developmental and/or environmental [8]. However, their impact on resources remains almost always the same [7].

At regional level, the gains or losses of different land use types in and around protected areas are mainly impacted by interactions between institutional and environmental factors [6]. The consequence of those LUCC can only be observed in a longer time frame [9].

Land use conversion due to increasing human and livestock population is a common experience in protected areas of most Eastern African countries [10]. Such a conversion of natural vegetation cover to other use types such as farmlands, grazing lands, human settlements and urban center has been shown to be a cause to loss of biodiversity, deforestation and land degradation [11]. Moreover, such changes, from forest to various land use types, in East Africa, including Ethiopia, were ranked as the highest in Africa at a rate of 0.94\% (1990-2000) and $0.97 \%$ per year (2000-2005) [12]. Unfortunately, the effect of such loss does not reveal the dramatic impact on the livelihood of the human populations unless its dynamics is examined within a focused \& local context [13].

Historical evidence shows that environmental problems such as surface runoff and sedimentation from the highland of Ethiopia and Eritrea have increased due to poor conservation and drastic land use/cover changes (LUCC) exacerbated by population pressure [14]. In the Afar rangelands where the climate is characterized by high temperature and low and irregular rainfall and where the Awash National Park (ANP) is partly located, LULC is indicated to be the main cause for reported poor living conditions of pastoral and agro-pastoral communities and a threat to sustainable resource conservation in the region [15]. In addition, the expansion of private and state farms at the expense of pastoralists' grazing land in the catchment area of Lake Beseka, Ethiopia, was reported to be the primary cause of LUCC between 1973 and 2008 [16]. The status of protected areas in Ethiopia was relatively in poor state until the end of the 1990s [17]. Further assessment after a decade also showed the continuation of the devastation caused by intense cultivation and high demand for grazing land in and around national parks, except for some positive developments reported in Bale Mountain and Semien Mountain National Parks [18]. More recently, emphasis has moved towards implementation of immediate intervention strategies such as in situ and ex situ conservation programs and a focus on the sustainable use of resources in national parks [19].

Theoretically, decentralization (devolution of power from federal to local governments) is considered as the most appropriate approach in managing natural resources because resources can be well identified and utilized rationally by local communities [20]. Also, local governments are better positioned than a central government to deliver public services and manage resources [21]. As a result, decentralization has emerged as the most significant tool of environmental and development policy in the last two decades [22].

In 1995 Ethiopia implemented a system of decentralization (Loop, 2002). About 16.4\% (186,000 $\mathrm{km}^{2}$ ) of the land in Ethiopia is protected [23] and the Ethiopian Wildlife Conservation Agency (EWCA) is responsible for its administration [24]. After the decentralization, in addition to the EWCA, regional governments also granted the right to make structural arrangements to implement decentralization in terms of creating conducive environment for a sustainable resource management [25].

The country's protected areas may have many challenges some of which are results of broader boarder conflicts among local communities [23]. Such factors have threatened the existence of many parks in the country [26]. The increasing livestock population and illegal exploitation of resources have impacted resources in Nechisar National Park [27]. Although Simen National Park was reported to show some positive development, infrastructural expansion in the surrounding area, deforestation, agriculture, hunting, and livestock grazing contributed to the deterioration of the park [28]. In Alatish National Park, habitat destruction to expand grazing land, poaching and forest fire were marked as primary contributing factors to the decline biological diversity [29] [30].

In the case of Awash National Park (ANP), a number of animal and plant species are reported to be endangered or critically endangered. The park has failed to protect the continuous decline of both faunal and floral communities [31]. In August 2011 a national conference of main stakeholders was held with the purpose of de- 
signing a mechanism to stop the radical habitat deterioration and species extinction that took place over the last four decades [32]. In light of current developments, understanding the patterns, causes, and consequences of LUCC would have a paramount importance to predicting changes relevant to the park in the future and help develop effective conservation and management strategies.

The objectives of the present study, therefore, were 1) to investigate the extent of LUCC in the ANP during a three-decade period (1972-2006); 2) to identify the key driving forces, causes and consequences of the observed LUCC of the ANP; 3) to examine the impact of LUCC on use and management of resources in the ANP, Ethiopia.

\section{Material and Methods}

\subsection{Study Area}

A detailed description of the study area, i.e. Awash National Park (Figure 1) and sampling scheme are given in [26].

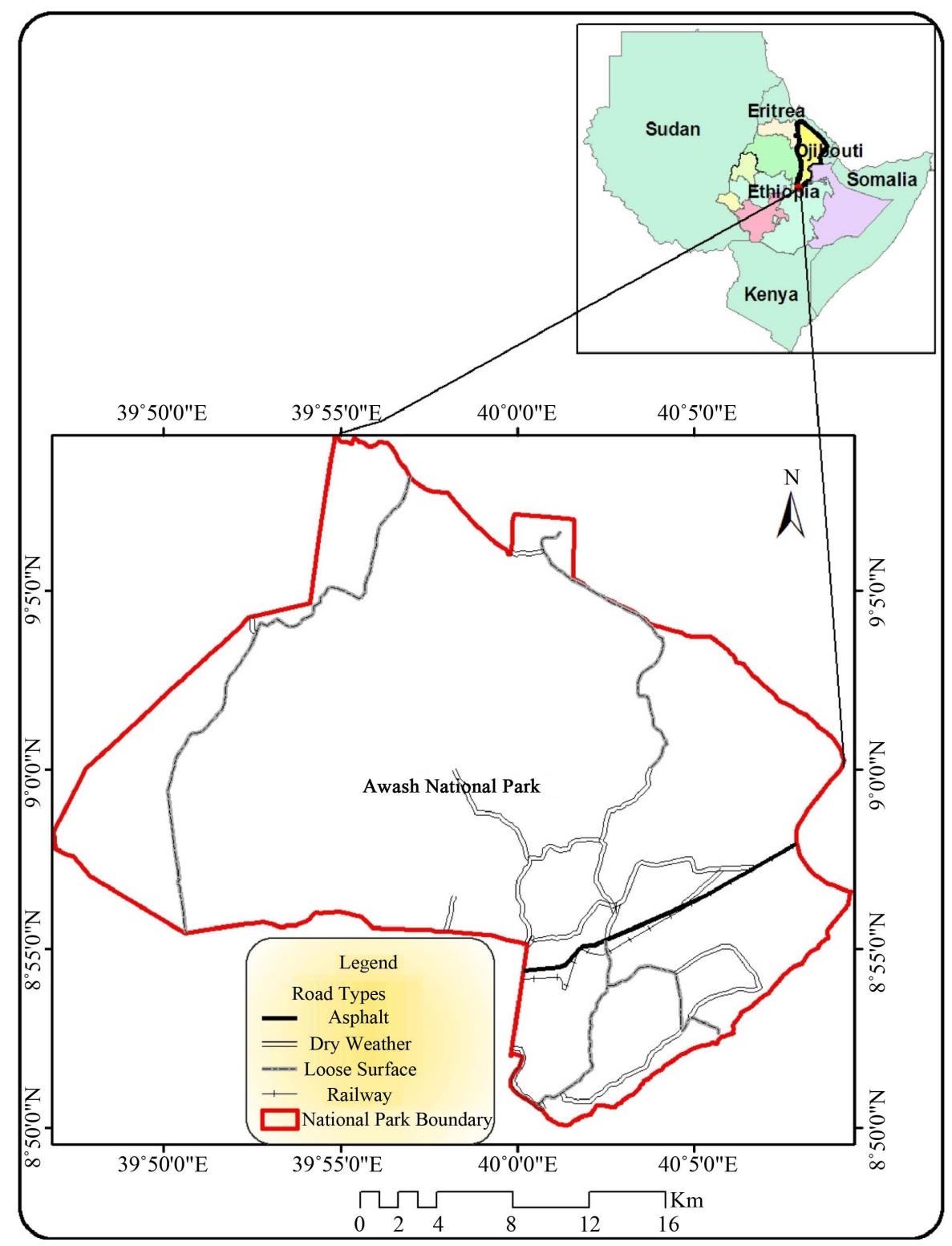

Figure 1. Map of the study area [55]. 


\subsection{Analysis of Land Use/Land Cover Changes}

We used black and white panchromatic aerial photographs of 1972 \& 1986, a 2006 multispectral SPOT image and a 1987 topographic map of the study area from Ethiopian Mapping Agency (EMA) to generate the LULC change for the three referenced periods of 1972, 1986 and 2006 (Table 1). These time periods were selected primarily because of data availability.

Aerial photographs were scanned with 600 dots per inch and the photo mosaic was made according to Universal Transverse Mercator projection (UTM Zone 37). The 1:50,000 topographic map was used as base map for geo-referencing the photo mosaic and the SPOT image with a similar projection. The spatial database was produced from the photographs and SPOT image using Arc Map 10 and superimposed on delineated park boundary. Field control points were the Addis-Djibouti railway line, the main asphalt road that cross ANP, the park administration buildings, the Awash River and other permanent structures. Chi-square goodness of fit test was used to test if there was significant change. Summarized quantitative household data was tested using Chisquare goodness of fit test. Theory of exponential (continuous population growth) was employed to check the status of the area's population growth and its effect as a driving force for LULC. Socio-economic data was analyzed using Statistical Package for the Social Science (SPSS version 17) [33].

\subsection{Socio-Economic Survey}

We employed multistage cluster sampling to pick 210 respondents within one kilometer distance from the park boundary (135 agro-pastoralists and 75 pastoralists) [34]. Our respondents came from twenty randomly selected villages of a total of 32 based on the set criteria of dependence on park resources.

Open ended questionnaires were designed to construct a time line of historical events. Interview data was summarized according to the "ecological time lines" [35] to distinguish different events/causes and consequences of LULC change. Time line was developed in close reference to the three governments that ruled the country during the study period, i.e. the Imperial (pre-1974), the "Derg” (from 1975 to 1991) and the Ethiopian People Democratic Republic Front (EPDRF) (from 1992 to the present).

We also gathered secondary data from government offices and non-governmental organizations in the form of population census data and park administration's annual reports.

\section{Results and Discussion}

\subsection{Land Use and Land Cover Changes since 1972}

The major LULC categories identified are given in Table 2. We identified six major LULC types: scattered bushland, shrubland, grassland, farmland, bare land and volcano crater (Figure 2).

Over the three decades we studied, similar trends of LULC changed at different rates of conversion were shown in all cover types except the scattered bushland. Scattered bushland was drastically reduced by $38.5 \%$ between 1972 and 1986 and by 29.4\% of the study area during the entire study period (Figure 2). The annual rate of change of scattered bushland was also the highest. With the exception of Siemen National Park [36], reports from Ethiopia show similar findings [36]-[38]. Also, in most East African countries, areas under forest cover were converted into grazing land, farmland or for charcoal production [39]. On the other hand in Costa Rica deforestation inside parks was negligible within the buffer zone of the park boundary [40].

Shrub encroachment was highest during the study period (Figure 2). The annual rate of expansion for shrubland was similar to what reference [15] reported for Afar rangelands between 1972 and 2007. Reference [41]

Table 1. Aerial photos and satellite images used in land use land cover change classification.

\begin{tabular}{cccccc}
\hline No & Image & Sensor & Resolution/Scale & Date of Acquisition & Path and Row \\
\hline 1 & 1972 Aerial Photograph & Analogue Frame Camera & $\mathrm{R}=5 \mathrm{~m} / 1: 50,000$ & December 1972 & - \\
2 & $\begin{array}{c}\text { 1986 Aerial Photograph } \\
3\end{array}$ & $\begin{array}{c}\text { Analogue Frame Camera } \\
\text { Spand Resource }\end{array}$ & $\mathrm{R}=5 \mathrm{~m} / 1: 50,000$ & February 1986 & - \\
& SPOtlite & SPOT Satellite & $\mathrm{R}=5 \mathrm{~m} /$ Floating & January 2006 & $167 / 54168 / 54$ \\
\hline
\end{tabular}

Source: Ethiopia Mapping Agency (EMA) http://www.gclf.org*. 
Table 2. Description of LULC categories.

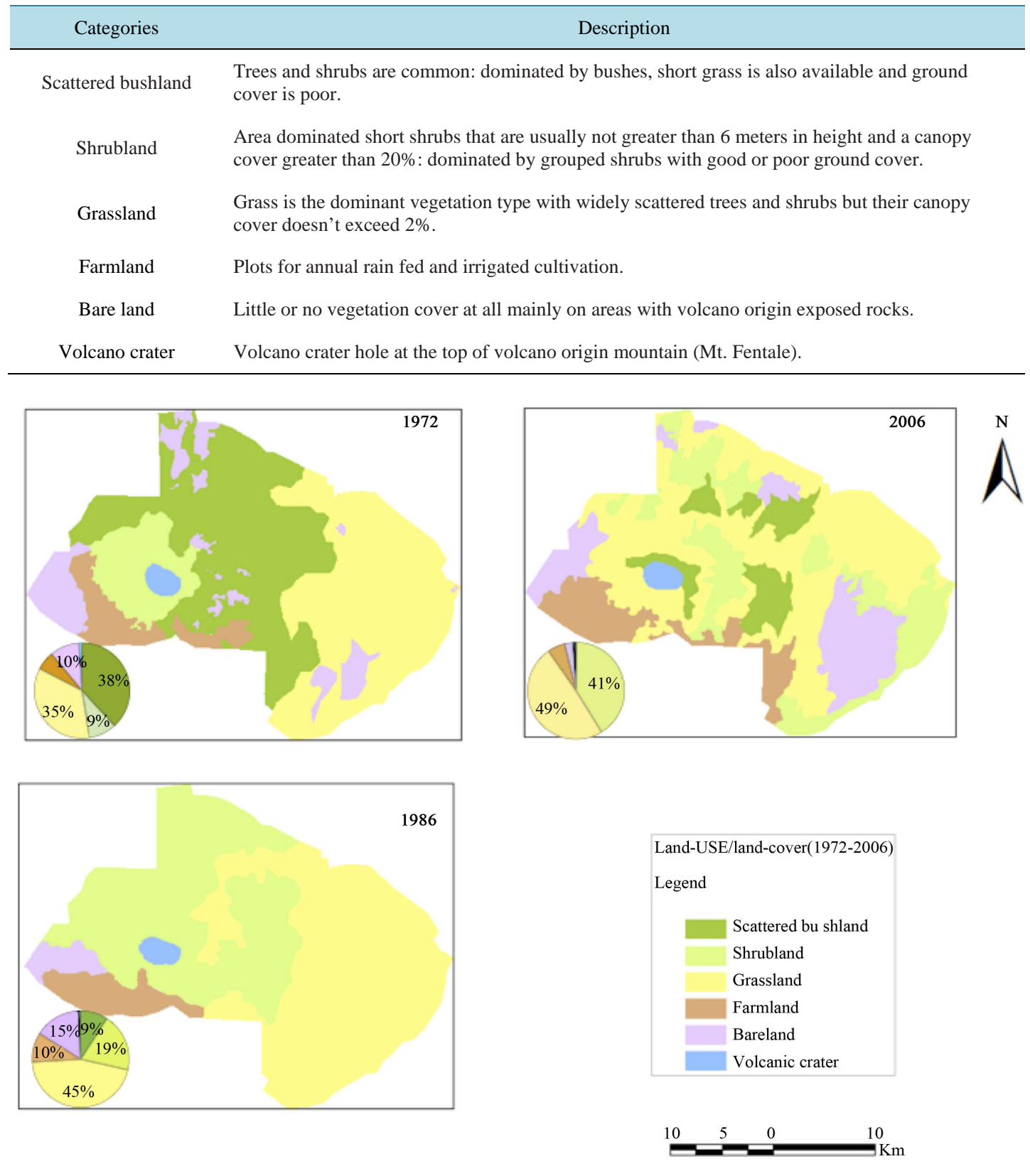

Figure 2. Land use land cover map of the study area for the year 1972, 1986 and 2006.

also showed an expansion of shrubland in SMNP, a park with a rigorous management strategy of agriculture and grazing land. On the contrary, shrubland seems to have shrunk in the country's highlands [42]-[44].

Grassland was the largest cover type in area between 1986 and 2006 and expanded by 14.2\% between 1972 and 1986 as well as by $10.5 \%$ of the study area during the entire study period (Figure 2) because of conversion of scattered bushland. Controlled burning within the boundary of ANP for the purpose of enhancing grass quality and reducing shrub and bush encroachment contributed to the expansion of grassland between 1993 and 1997 [17]. Menale et al. [41] reported a similar expansion of grassland in the SMNP. On the other hand, grassland seemed to decline in different areas of the country where sedentary economic activity and permanent settlement was common [36]-[38] [43].

Farmland expanded during the entire period (Figure 2). The current Ethiopian government has encouraged 
pastoralists to engage in agro-pastoral activities. Overall high farmland expansion characterized most parts of the country during the past 15 years [15] [36]-[38] [41]-[43] [45].

In Kibale National Park, Uganda, expansion of agricultural land was reported in the surrounding areas due to increasing number of immigrants [46]. In most East African countries expansion of farm land at the expense of forest covered area was coupled principally with the availability of water for crop production [47].

It was common to see land without vegetation cover particularly at the top of Mt Fentale, and this bare land expanded by $4.9 \%$ during the entire three decades (Figure 2).

\subsection{Drivers of Land Use/Land Cover Change}

From a range of demographic, socio-economic and infrastructure related factors, 12 driving forces were identified (Figure 3).

Population growth was reported to be the main driving factor pre-and post-decentralization. Most respondents (74\%) agree that population growth was a potential driver of the cover change pre-1995 (X2 = 46.7, df $=1, \mathrm{P}<$ 0.0001, Figure 3) and post-1995 (X2 = 35.2, df = 1, P $<0.0001$, Figure 3). Specific population pressure was pinpointed. For example, Kereyou communities underscored that the immigration of the Ittu people towards Fentale district has caused increased competition over resources and contributed to the observed LULC changes. The immigration of Ittu to the Kereyou's locality was to avoid persecution by other communities [17].

Based on Ethiopian national population and housing survey [48] [49] in 1984, 1994 and 2007, the total population of the Afar and the Kereyou-Ittu people has increased rapidly by $65 \%$. Over the same period, the population on the Kereyou-Ittu side increased by 71\% [49] [50]. This population increase was reported as the main cause for LULC changes including the expansion of farmlands at the expense of grazing lands [38] [43] [51] [52] [53]. Reference [14] argues that there are positive implications of population increment when linked to reducing runoff through practicing land use and other conservation activities.

\subsection{Institutional Factors}

The most important drivers of the observed LULC changes pre-1995 were the combined effects of the land reform policy and changes in park boundary followed by climatic changes such as drought $(\mathrm{X} 2=101.7, \mathrm{df}=1$, $\mathrm{P}<0.0001$, Figure 3$)$. Other factors were the expansion of both government and private farms and civil war $(\mathrm{X} 2=$ 88.4, $\mathrm{df}=1, \mathrm{P}<0.0001)$.

Livestock grazing was a predominant driving force post-1995 followed by expansion of government \& private farms around the study area $(\mathrm{X} 2=164.0, \mathrm{df}=1, \mathrm{P}<0.0001)$. Park officials reported the expansion of irri-

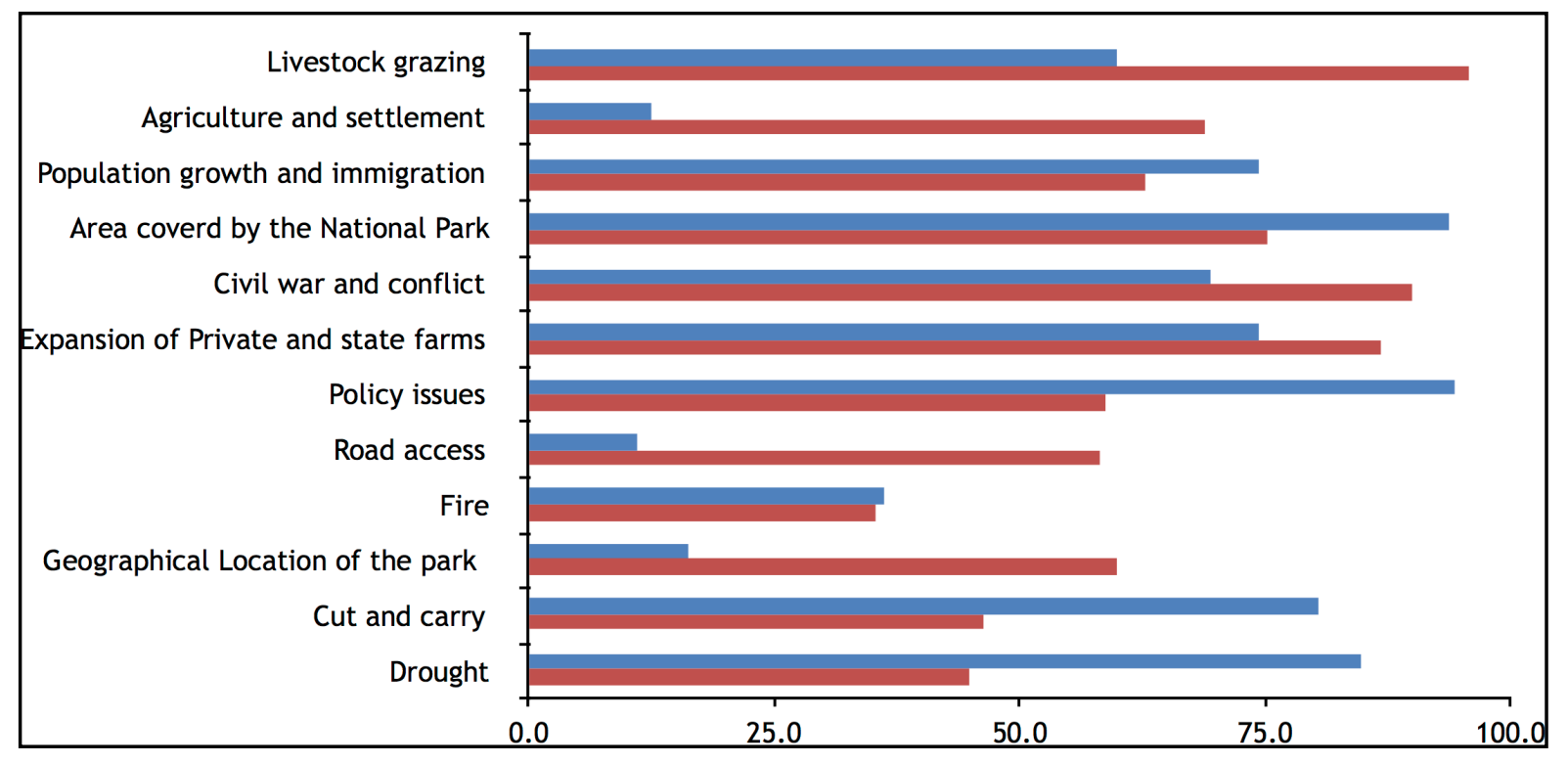

Figure 3. Key driving forces of LULC changes. 
gation around the ANP as having an indirect effect on the park in addition to its contribution to the land use and land cove changes in the park surroundings. For instance, Metahara sugar plantation denied water access to the Kereyou-Ittu and their livestock and that forced them to move into the ANP in search of watering site. A similar expansion of irrigated and rain fed agriculture in Afar and Oromo communities around the ANP have been implicated to be the causes for the conversion of different land cover types into farmland [53] [54].

Changes in the boundary of the park was identified as the third driving force post-1995 (X2 = 138.2, df $=1, \mathrm{P}<$ 0.0001). Informants indicated the need for amendment to the current boundary to avoid vagueness, inaccuracy and to make it easily recognizable by local communities. Both pastoralists and agro-pastoralists $(\mathrm{X} 2=127.2$, $\mathrm{df}=$ $1, \mathrm{P}<0.0001)$ underscored the problem related to livestock production in their locality which forced them to engage in non-pastoralist activities such as irrigation and rainfed agriculture which incased the demand for new LULC types.

\subsection{Perceptions of Local Communities}

Similar to their perceptions of drivers of LULC changes, pastoralists and agro-pastoralists were in a position to point out major events and consequences of the observed LULC changes in terms of their incidence period during the Imperior (before 1974), the "Derg” regime (from 1975 to 1991) and the Ethiopian People’s Revolutionary Democratic Front (EPDRF) from 1991 to the present.

Our data shows that the ecological condition of land cover around the ANP was better during the time of the Emperor (before 1974) than the period of the two successive regimes. The local communities lamented on the fact that the Imperial regime made an attempt to negotiate on some issues with them before the establishment of the ANP. Then the Kereyou requested the pushing back of the Ittu to the surrounding of Harar town as a pre-condition for the establishment of the park. However, after the establishment of the park, the Kereyou, who believed to be indigenous owners of the area, presented their complaints to the Emperor about the unfulfilled promises made to them. The immigration of the Ittue towards land owned by Kereyou and the removal of the Kereyou without comparable compensation was an unfortunate decision which led to the development of a more negative attitude towards the value of ANP from the beginning. However, the communities did not forget the good steps the Emperor took in providing $250 \mathrm{~km}^{2}$ of land to the Kereyou as compensation. All pastoralists reported that permanently uncultivated and unsettled land during the Emperor was considered state property. And that was the main reason for changes in land ownership from the Kereyou to the Ittu and expropriation of pastureland for sugar cane plantation (Table 3), a cause for an increased demand for pastureland and water points in and surrounding the park.

The time between 1972 and 1986 was recognized as a hard time for the communities. Activities such as boundary demarcation of the ANP without the knowledge of the local communities and park resources were protection by force. Moreover, the 1975/76 drought was a cause for an unforgettable devastation both on the community and the park. The drought forced that park administrators to be lenient: they gave permission to pastoralists to have access to grazing land, settlement and borehole inside the ANP. The prolonged civil war in the country during the Derg regime was also categorized as one reason for the government's neglect of communitybased solutions. Furthermore, conflicts among local communities continue to cause the loss of human life and livestock raiding. The dramatic loss of larger mammal populations due to poaching of wildlife by the Argobba and government soldiers was reported during the Derg regime [17]. The 1975 land reform policy did not set any genuine steps to ensure land holding rights of pastoralists.

Pastoralists and agro-pastoralists universally agreed that the current government (EPDRF) has a better understanding of the pastoralists' production system and is engaged in better economic and infrastructure development activities locally. However, the expansion of large scale commercial farming did not take into consideration the conservation of park resources. Expansion of state and private farms has aggravated the scarcity of grazing land for pastoralists. Pastoralists also claim that infrastructure development, mainly access roads and railway, has affected animal populations in the park negatively. Road kills are very common at the Addis-Dire Dawa asphalt road and Addis-Dire Dawa railway. The current government has encouraged settlements and agro-pastoral activities, which unfortunately in turn create a higher demand for firewood, charcoal and house construction in and around the park. All agree that, similar to previous policies, current land tenure policy is unable to resolve land tenure insecurities and related land use challenges of pastoralists. 
Table 3. Major events, causes and consequences of the LULC changes between 1972 and 2006 years as s seen by local key informants in Afar and Kereyou-Ittu community.

\begin{tabular}{|c|c|c|}
\hline Time Period & Major Causative Event & Consequences \\
\hline \multirow{3}{*}{$\begin{array}{l}\text { Before } 1972 \text { (the reign of } \\
\text { Emperor Hailesellassie) }\end{array}$} & Immigration of the Ittu to Kereyou's land & Population Increment around Kereyou settlements \\
\hline & Complaint of the community to the Emperor & Compensation of 600 “Gasha” (250 km²) of land \\
\hline & $\begin{array}{l}\text { "No man's land” land tenure system (land } \\
\text { belongs to the land lord) }\end{array}$ & $\begin{array}{l}\text { Land alienation and expropriation of land for } \\
\text { non-pastoral activities }\end{array}$ \\
\hline \multirow{6}{*}{$\begin{array}{l}\text { Between } 1972 \text { \& } 1986 \text { (the } \\
\text { "Derg” regime) }\end{array}$} & Boundary demarcation of ANP by the Derg & $\begin{array}{l}\text { Enmity between the local communities and park } \\
\text { workers }\end{array}$ \\
\hline & $\begin{array}{l}\text { High poaching by Derge soldiers and Argoba } \\
\text { people }\end{array}$ & Reduction of large mammal population \\
\hline & Drought (1975/76) & $\begin{array}{l}\text { Permission of grazing land, settlement and borehole } \\
\text { construction inside the ANP }\end{array}$ \\
\hline & Increased immigration of Ittu & Migration of the Kereyou toward the park \\
\hline & Civil war and conflict & $\begin{array}{l}\text { Less attention from the government and the loss of } \\
\text { human lives and looting of livestock }\end{array}$ \\
\hline & $\begin{array}{l}\text { The } 1975 \text { land reform in principle granted } \\
\text { pastoralists right to grazing land }\end{array}$ & $\begin{array}{l}\text { Didn't improve the land right position of } \\
\text { pastoralists }\end{array}$ \\
\hline \multirow{6}{*}{$\begin{array}{l}\text { Between } 1986 \text { \& } 2006 \text { (the } \\
\text { present government } \\
\text { (EPDRF)) }\end{array}$} & Expansion of government and private farms & $\begin{array}{l}\text { Land alienation and pastoralists moved into the } \\
\text { ANP }\end{array}$ \\
\hline & Excessive overstocking & $\begin{array}{l}\text { Low forage yield and further expansion into the } \\
\text { ANP }\end{array}$ \\
\hline & High conflict & $\begin{array}{l}\text { Insecurity became high and communities moved } \\
\text { further into the ANP }\end{array}$ \\
\hline & Infrastructure development (road and railway) & Killing of animals increased \\
\hline & $\begin{array}{l}\text { Expansion of sedentrization and } \\
\text { agro-pastoralist way of life }\end{array}$ & $\begin{array}{l}\text { High demand for firewood, charcoal and house } \\
\text { construction }\end{array}$ \\
\hline & $\begin{array}{l}\text { Establishment of several institutional } \\
\text { arrangements }\end{array}$ & $\begin{array}{l}\text { In principle official recognition of the pastoral } \\
\text { production system }\end{array}$ \\
\hline
\end{tabular}

\section{Concluding Remarks}

Our study has revealed that during the three-decade time period we covered, there was an expansion of grassland, farmland and open land in Awash National Park, Ethiopia. Continued land use/land cover changes coupled with increasing demand for resources have heavily affected the fauna and flora of the park. This change cannot be ignored altogether because it has unquestionable consequences in relation to the livelihood of communities surrounding the park. Reducing human and livestock pressure, and delimiting the park boundary unambiguously would be critical as the first step in ensuring the sustainable future of the park.

\section{Acknowledgements}

We thank the Kereyou-Ittue and Afar communities for their valuable time. Special thanks go to Awash National Park administrators and the owner of Awash Lodge for allowing us to conduct the study in their premises. Jigjiga University supported SB financially.

\section{References}

[1] McCusker, B. and Weiner, D. (2003) GIS Representations of Nature, Political Ecology, and the Study of Land Use and Land Cover Change in South Africa. In: Zimmerer, K. and Bassett, T., Eds., Political Ecology: An Integrative Approach to Geography and Environment-Development Studies, Guilford, New York, 200-221. 
[2] Moore, D. (1993) Contesting Terrain in Zimbabwe’s Eastern Highlands. Economic Geography, 69, 380-402. http://dx.doi.org/10.2307/143596

[3] Levin, R. and Weiner, D. (1997) Towards the Development of a Popular and Participatory Land Reform Program in a Democratic South Africa. In: Levin, R. and Weiner, D., Eds., No More Tears: Struggles for Land in Mpumalanga, South Africa, Africa World Press, Trenton.

[4] Geist, H.J. (2002) The IGBP-IHDP Joint Core Project on Land-Use and Land-Cover Change (LUCC). In: Badran, A., et al., Eds., Land Use and Land Cover Vol. 1, the Encyclopedia of Life Support Systems.

[5] Tekle, K. and Hedlund, L. (2000) Land Cover Changes between 1958 and 1986 in Kalu District, Southern Wello, Ethiopia. Mountain Research and Development, 20, 42-51. http://dx.doi.org/10.1659/0276-4741(2000)020[0042:LCCBAI]2.0.CO;2

[6] Sherbinin, A. (2002) Thematic Guide to Land-Use and Land-Cover Change (LUCC). Center for International Earth Science Information Network (CIESIN) Columbia University Palisades, New York. http://sedac.ciesin.columbia.edu/tg/guide_main.jsp.

[7] Lambin, E.F., Geist, H.J. and Lepers, E. (2003) Dynamics of Land-Use and Land-Cover Change Tropical Regions. Annual Review of Environment and Resources, 28, 205-241. http://dx.doi.org/10.1146/annurev.energy.28.050302.105459

[8] Wood, A., Stedman-Edwards, P. and Mang, J. (2000) Ten Case Studies—An Overview. In: Wood, A., Stedman-Edwards, P. and Mang, J., Eds., The Root Cause of Biodiversity Loss, Earthscane Publication Ltd., London, 36-57.

[9] Galicia, L. and Garcia-Romer, A. (2007) Land Use/Cover Change in Highland Temperate Forests in the Izatapopo National Park, Central Mexico. Mountain Research and Development, 22, 48-57. http://dx.doi.org/10.1659/0276-4741(2007)27[48:LUALCC]2.0.CO;2

[10] Pomeroy, D., Tukahirwa, J., Mugisha, S., Nanyunja, R., Namaganda, M. and Chelimo N (2003) Linkages between Change in Land Use, Land Degradation and Biodiversity in SW Uganda. www.lucideastafrica.org

[11] Maitima, J.M., Mugatha, S.M., Reid, R.S., Gachimbi, L.N., Majule, A., Lyaruu, H., Pomery, D., Mathai, S. and Mugisha, S. (2009) The Linkages between Land Use Change, Land Degradation and Biodiversity across East Africa. African Journal of Environmental Science and Technology, 3, 310-325.

[12] Food and Agricultural Organization (FAO) (2007) State of the World's Forests 2007. http://www.fao.org/docrep/009/a0773e/a0773e00.HTM

[13] Gardew, F., Sandewall, M., Soderberg, U. and Campbell, B. (2009) Land-Use and Land-Cover Dynamics in the Central Rift Valley of Ethiopia. Environmental Management, 44, 683-694. http://dx.doi.org/10.1007/s00267-009-9355-Z

[14] Hurni, H., Kebede, T. and Gete, T. (2005) The Implication of Changes in Population, Land Use and Land Management for Surface Runoff for Upper Nile Basin Area of Ethiopia. Mountain Research and Development, 25, 147-154. http://dx.doi.org/10.1659/0276-4741(2005)025[0147:TIOCIP]2.0.CO;2

[15] Tsegaye, D., Moea, R.S., Vedeldc, P. and Ermias, A. (2010) Land-Use/Cover Dynamics in Northern Afar Rangelands, Ethiopia. Journal of Agriculture Ecosystems and Environment, 139, 174-180. http://dx.doi.org/10.1016/j.agee.2010.07.017

[16] Megersa, O.D. (2012) Analyzing Decadal Land Use/Cover Dynamics of the Lake Basaka Catchment (Main Ethiopian Rift) Using LANDSAT Imagery and GIS. Lakes \& Reservoirs: Research and Management, 17, 11-24. http://dx.doi.org/10.1016/j.agee.2010.07.017

[17] Jacobs, M.J. and Schroeder, A. (1997) Awash National Park Management Plan: 1993-1997. EWCO, Addis Ababa.

[18] Duckworth, F.W. (2002) An Assessment of Ethiopia’s Wildlife Situation. Ethiopian Reporter, Ethiopia.

[19] Institute of Biological Convention, IBC (2009) Ethiopia’s 4th Country Report. Institute of Biodiversity Conservation, Addis Ababa, 4-8 May 2009.

[20] Larson, A.M. (2002) Natural Resources and Decentralization in Nicaragua: Are Local Governments up to the Job? World Development, 30, 17-31. http://dx.doi.org/10.1016/S0305-750X(01)00098-5

[21] Zou, H.F. and Davoodi, H. (1997) Fiscal Decentralization and Economic Growth: A Cross-Country Study. Journal of Urban Economics, 43, 244-257.

[22] Agrawal, A. and Gupta, A. (2005) Decentralization and Participation: The Governance of Common Pool Resources in Nepal's Terai. World Development, 33, 1101-1114. http://dx.doi.org/10.1016/j.worlddev.2005.04.009

[23] Ashenafi, Z.T. and Leader-Williams, N. (2005) Indigenous Common Property Resource Management in the Central Highlands of Ethiopia. Human Ecology, 33, 539-563. http://dx.doi.org/10.1007/s10745-005-5159-9

[24] Council of Ministers (2008) Wildlife Development, Conservation and Utilization. Council of Ministers Regulation No 163/2008, 4567-4600.

[25] Hurni, H. (2003) The Simen Mountains National Park World Heritage Site. An Interview with Leykun Abune, Pro- 
gram Coordinator, Simen Mountains Integrated Development Program. Mountain Research and Development, 23, 238239. http://dx.doi.org/10.1659/0276-4741(2003)023[0238:TSMNPW]2.0.CO;2

[26] Belay, S., Amsalu, A. and Abebe, E. (2012) Awash National Park, Ethiopia: Use Policy Ethnic Conflict and Sustainable Resource Conservation in the Context of Decentralization. Africa Journal of Ecology, 51, 122-129. http://dx.doi.org/10.1111/aje.12015

[27] Demeke, D. and Afework, B. (2011) Population Status and Human Impact on the Endangered Swayne’s Hartebeest (Alcelaphus Buselaphus Swaynei) in Nechsar Plains, Nechsar National Park, Ethiopia. African Journal of Ecology, 49, 311-319. http://dx.doi.org/10.1111/j.1365-2028.2011.01266.x

[28] Hurni, H., Ludi, E., Leykun, A. and Mulugeta, A. (2008) Simen Mountains National Park, Ethiopia: Evolution of Institutional Approaches to Its Management since 1969. In: Galvin, M. and Haller, T., Eds., People, Protected Areas and Global Change: Participatory Conservation in Latin America, Africa, Asia and Europe. Perspectives of the Swiss National Centre of Competence in Research (NCCR), NCCR North-South, c/o Centre for Development and Environment, University of Bern, Institute of Geography, Bern, 287-324.

[29] Girma, M. and Afework, B. (2008) Diversity, Distribution and Habitat Association of Large Mammals of Altash, North Gonder, Ethiopia. Acta Zoological Sinca, 54, 20-29.

[30] Chekol, T., Bekele, A. and Balakrishnan, M. (2012) Population Density, Biomass and Habitat Association of Rodents and Insectivores in Pawe Area, Northwestern Ethiopia. Tropical Ecology, 53, 15-24.

[31] Eyasu, E. (2008) Pastoralists in Southern Ethiopia: Dispossession, Access to Resources and Dialogue with Policy Makers. Dry Land Coordination Group (DCG) Report No. 53.

[32] EWCA (2011) Conference Report on Rescuing Awash National Park. Adama/Nazreth, 24-25 August 2011.

[33] SPSS, Statistical Package for Social Science (1993-2007) SPSS for Windows Standard Version. SPSS Inc., Chicago.

[34] Robinson, C. (2002) Real World Research: A Resource for Social Scientists and Practitioner-Researchers. 2nd Edition, Blackwell Publishing Ltd., Oxford.

[35] Reid, R.S., Kruska, R.L., Muthui, N., Taye, A., Wotton, S., Wilson, C.J. and Mulatu, W. (2000) Land-Use and LandCover Dynamics in Response to Changes in Climatic, Biological and Socio-Political Forces: The Case of Southwestern Ethiopia. Landscape Ecology, 15, 339-355. http://dx.doi.org/10.1023/A:1008177712995

[36] Gete, Z. and Hurni, H. (2001) Implication of Land Use and Land Cover Dynamics for Mountain Resource Degradation in the Northwestern Ethiopian Highlands. Mountain Research and Development, 21, 184-191. http://dx.doi.org/10.1659/0276-4741(2001)021[0184:IOLUAL]2.0.CO;2

[37] Emiru, T.S. and Taye, A. (2012) Land Use/Cover Dynamics in Lowland Ethiopia since 1957: The Case of Mandura District, Benshangul-Gumuz Regional State. Journal of Biodiversity and Environmental Sciences, 8, 36-49.

[38] Fesseha, G., Gebrekidan, H., Kibret, K., Yitaferu, B. and Bedadi, B. (2011) Analysis of Land Use/Land Cover Changes in the Debre-Mewi Watershed at the Upper Catchment of the Blue Nile Basin, Northwest Ethiopia. Journal of Biodiversity and Environmental Sciences, 6, 184-198.

[39] Olson, J.M., Misan, S., Campbell, D.J., Mbonile, M. and Mugisha, S. (2004) Land Use Change Impact and Dynamics (LUCID) Project Working Paper. International Livestock Research Institute, Nairobi.

[40] Azofeifaa, G.S., Daily, G.C., Pfaffc, A.S.P. and Busch, C. (2003) Integrity and Isolation of Costa Rica’s National Parks and Biological Reserves: Examining the Dynamics of Land-Cover Change. Biological Conservation, 109, 123-135. http://dx.doi.org/10.1016/S0006-3207(02)00145-3

[41] Menale, W., Schneider, W., Assefa, M.M. and Demel, T. (2011) Spatial and Temporal Land Cover Changes in the Simen Mountains National Park, a World Heritage Site in Northwestern Ethiopia. Remote Sensing, 3, 752-766. http://dx.doi.org/10.3390/rs3040752

[42] Kibrom, T. and Hedlund, L. (2000) Land Cover Changes between 1958 and 1986 in Kalu District, Southern Wello, Ethiopia. Mountain Research and Development, 20, 42-51. http://dx.doi.org/10.1659/0276-4741(2000)020[0042:LCCBAI]2.0.CO;2

[43] Woldeamlak, B. (2003) Towards Integrated Watershed Management in Highland Ethiopia: The Chemoga Watershed Case Study. Ph.D. Thesis, Wageningen University, Wageningen.

[44] Berhan, G., Hill, S., Tadesse, T. and Atnafu, S. (2011) Using Satellite Images for Drought Monitoring: A Knowledge Discovery Approach. Journal of Strategic Innovation and Sustainability, 7, 135-153.

[45] Abate, S. (2011) Evaluating the Land Use and Land Cover Dynamics in Borenaworeda of South Wollo Highlands, Ethiopia. Journal of Sustainable Development in Africa, 13, 87-107.

[46] Majaliwa, J.G.M., Twongyirwe, R., Nyenje, R., Oluka, M., Ongom, B., Sirike, J. and Mfitumukiza, D. (2010) The Effect of Land Cover Change on Soil Properties around Kibale National Park in South Western Uganda. Applied and Environmental Soil Science, 2010, Article ID: 185689. http://dx.doi.org/10.1155/2010/185689 
[47] Reid, R.S., Gachimbi, L.N., Worden, J., Wangui, E.E., Mathai, S., Mugatha, S.M., Campbell, D.J., Maitima, J.M., Butt, B., Gichohoi, H. and Ogol, E. (2004) Linkages between Changes in Land Use, Biodiversity and Land Degradation in the Loitokitok Area of Kenya. LUCID Working Paper 49, International Livestock Research Institute and the United Nations Environment Programme/Division of Global Environment Facility Coordination, Nairobi.

[48] Central Statistics Agency (CSA) (1994) National Population Statistics. Federal Democratic Republic of Ethiopia, Central Statistical Authority, Addis Ababa.

[49] Central Statistics Agency (CSA) (2007) National Population Statistics. Federal Democratic Republic of Ethiopia, Central Statistical Authority, Addis Ababa.

[50] Central Statistics Agency (CSA) (2004) Annual Report. Addis Ababa.

[51] Amsalu, A. (2006) Best Practices in Soil and Water Conservation in Beressa Watershed, Highlands of Ethiopia. Ph.D. Thesis, Wageningen Agricultural University, Wageningen.

[52] Shibru, T. and Kifle, L. (1998) Environmental Management in Ethiopia: Have the National Conservation Plans Worked? Organization for Social Science Research in Eastern and Southern Africa (OSSRIA) Environmental Forum Publications Series No. 1, Addis Ababa.

[53] Ayalew, G. (2001) Conflict Management, Resolution and Institutions among the Karrayu and Their Neighbors. In: Mohammed Salih, M.A., Dietz, T. and Ahmad, A.G.M., Eds., African Pastoralism: Conflicts, Institutions and Government, Organization of Social Science Research in Eastern Africa (OSSREA), Nairobi.

[54] Getachew, G., Nigatu, A., Abule, I., Gezahegne, A. and Shimelis, B. (2007) Pastoral Livelihoods in Afar and Kereyu the Case of Pastoral Communities in and around Awash National Park. Pastoral Livestock Systems: Opportunities and Challenges as a Livelihood Strategy. Proceedings of the 15th Annual Conference of the Ethiopian Society of Animal Production, Addis Ababa, 4-6 October 2007.

[55] Ethiopian Mapping Authority (EMA) (1987) 1:50,000 Topographic Map Series of Awash Areba, Addis Ababa. 
Scientific Research Publishing (SCIRP) is one of the largest Open Access journal publishers. It is currently publishing more than 200 open access, online, peer-reviewed journals covering a wide range of academic disciplines. SCIRP serves the worldwide academic communities and contributes to the progress and application of science with its publication.

Other selected journals from SCIRP are listed as below. Submit your manuscript to us via either submit@scirp.org or Online Submission Portal.
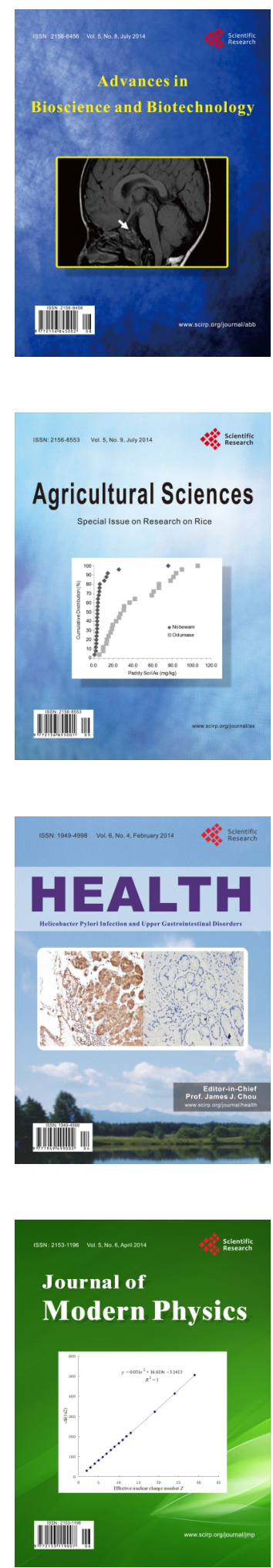
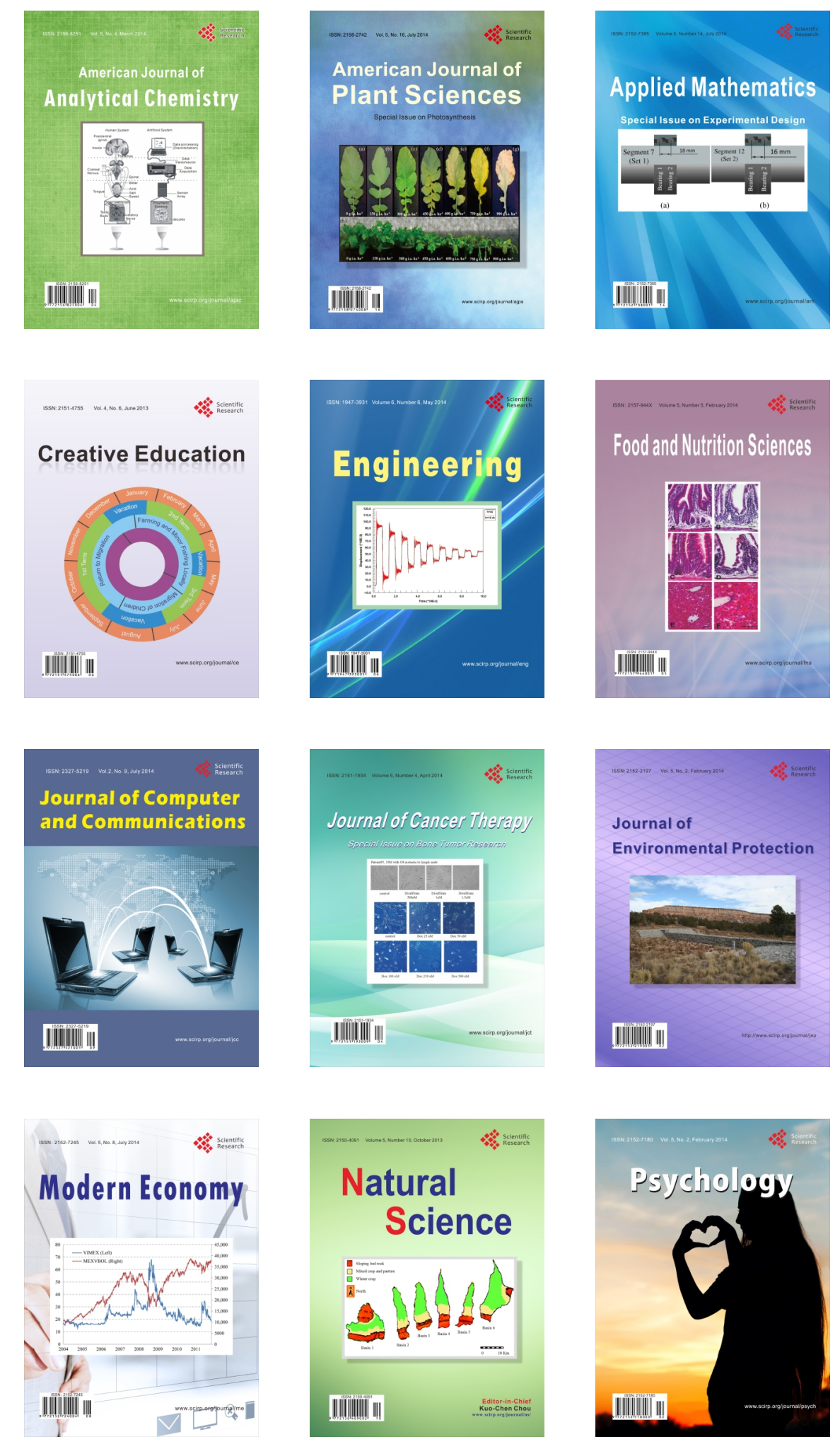